\title{
Integration of Information and Communication Technologies in Teaching by Female Academic Teaching Staff in the Higher Education Sector in Mauritius
}

\author{
Noshmee D. Baguant ${ }^{1}$ \\ ${ }^{1}$ PhD Student at University of KwaZulu-Natal, South Africa \\ Correspondence: Noshmee D. Baguant, PhD Student at University of KwaZulu-Natal, South Africa
}

Received: October 17, 2018

Accepted: July 29, 2019

Online Published: August 19, 2019

doi:10.5430/ijhe.v8n5p56

URL: https://doi.org/10.5430/ijhe.v8n5p56

\begin{abstract}
Information and Communication Technologies (ICT) is increasingly being used to support the process of academic teaching in the higher education sector. However, it is imperative to understand the causes for minimal utilisation of ICT tools by female academic teaching staff in their teaching process, resulting in gender inequity in technology. The research examined the correlation between ICT integration in the teaching process by female academic teaching staff in the higher education sector in Mauritius and the factors that could improve such integration in line. Futures thinking methodology was used for this study to address policy, strategies and actions to support appropriate futures. It comprised an evaluation of the sources and causes of change to map a probable future and a preferable future. The future thinking methods included signalling, horizon scanning, future wheel analysis, alternate futures framework and determining scenarios. As a result of the research, recommendations were made to assist policy makers and decision makers to develop evidence based policies to address gender inequity in the use of technology in higher education.
\end{abstract}

Keywords: ICT integration, female academic teaching staff, higher education

\section{Introduction}

\subsection{Introduce the Problem}

ICT integration in teaching in a higher education institution is encouraged by a shift in paradigm in the teaching process from chalk and talk to innovative digital content. The integration of ICT in teaching-learning processes heightens the need to offer academic teaching staff the most enjoyable teaching experience. Kler (2015) identified ICT as an effective channel with the ability to increase instructive communication between the academic teaching staff and the student in a classroom equipped with appropriate educational technologies. The demand for ICT integration in the curriculum has become a global concern and is of great significance towards achieving the Millennium Development Goals and the goals of Education for All.

According to Muro and Gabriel (2016), the environment surrounding women, reduces the latter's morale to engage in ICT professions because since childhood girls practise soft tasks while boys do the hard and technical tasks. Classroom activities like tutorials, presentations, discussions, laboratory projects and invited guest lecturers can enhance the teaching processes of academic teaching staff by merging ICT with teaching (Prabowo, 2007). The integration of ICT in the teaching process does not benefit only the teaching academic staff but the students as well. ICT integration in the curriculum increases student exposure to digital contents, which has significant and positive impact on student achievement, especially in terms of knowledge, comprehension, practical or technical skills and presentation skills in subject areas such as mathematics and science. However, irrespective of the subject being lectured (ranging from Humanities to Engineering subjects), the higher education sector in Mauritius can be one where ICT cuts across all subjects of study and is implemented by each and every academic teaching staff. Although most lecture theatres/classrooms in higher education institutions in Mauritius possess projectors for the digital delivery of the lectures and even some higher education institutions offer the e-learning platform to students, it is generally observed that female academic teaching staff make minimal use of ICT tools in their teaching process and such integration is only the tip of the iceberg compared to developing countries. The research questions for the study are as follows: 
a) What is the relationship between ICT integration in teaching and female academic teaching staff in the higher education sector in Mauritius?

b) How does ICT integration in teaching by female academic teaching staff in the higher education sector in Mauritius influence a knowledge society?

c) How can Government improve ICT integration in teaching by female academic teaching staff in the higher education sector in Mauritius?

For the successful development of Mauritius as a knowledge society, gender must not be a blocking factor for the usage of ICT. The development of an ICT culture in Mauritius would be the key to attain the knowledge society and gender equity especially in the field of ICT. In the same manner, ICT integration in the teaching process will not be a matter of gender issues. All academic teaching staff will be in a position to operate a variety of ICT tools, which will help them to improve their teaching process. The study has as objectives to offer the possibility to examine the relationship between gender and ICT integration in teaching by female academic teaching staff in the higher education sector in Mauritius and to understand how gender influences such integration given that ICT is an important enabler towards developing a knowledge society.

\subsection{Significance of the Study}

As education is an important pillar of any economy, ICT integration in the teaching process is critical to make Mauritius shine across the globe in terms of its technological advancement. The conclusion and the recommendations of this study could assist as a guiding tool for effective implementation and use of ICT tools in the teaching process in the higher education sector especially for female academic teaching staff. This study could also help the Government of Mauritius (including curriculum developers and policy makers) to make informed decisions on how to effectively implement ICT integration in a classroom milieu for female academic teaching staff. This study elaborates on the challenges facing female academic staff in using ICT in classroom when delivering lectures as well as in other administrative processes. Furthermore, this study focuses not only on the strengths and opportunities of ICT integration in the teaching process in the higher education sector by female academic teaching staff but also on its weaknesses including challenges hindering ICT integration particularly from a gender perspective. ICT integration in teaching by female academic teaching staff in the higher education sector is considerably under-researched in the Mauritian context and the study will contribute to this body of knowledge.

\subsection{Literature Review}

\subsubsection{ICT and Education}

Education is the backbone for progress of any country and is one of the most important indicators for developing countries to achieve sustainable growth. Education is seen as the main input for a society to be considered a knowledge society (Demir, Genc, Alp and Yildirim, 2015). Ciolan, Petrescu, Radulescu and Bucur (2014) defined a knowledge society as a learning society with knowledge and competences evolving continuously. ICT has profoundly changed our society and are the basis of today's knowledge society (Almerich, Orellana, Suárez-Rodríguez and Díaz-García, 2016). According to Almekhlafi, Ismail, and Al-Mekhlafy (2017), all teachers regardless of gender perceive technology as a tool that can promote language teaching and learning environment ICT is well on its way to being an important engine to boost the higher education sector in many countries. ICT plays an important role in building a knowledge society when taking into consideration its social, cultural and economic contribution to the country. Major changes in education are required to enable Mauritius to respond to high quality education of international standard and ICT can be used to merge technological innovation, information and communication to the development of the knowledge society.

\subsubsection{Academic Teaching Staff and ICT Integration in Teaching}

ICT has a fundamental role in nearly all phases of the educational process, especially in higher education (Achimugu, Oluwagbemi and Oluwaranti, 2010). Higher education institutions have to transform their academic structures to adjust to the new communicative dynamics of access to information and knowledge and of social relationship (Durat and Mengual-Andrés, 2014). Bauer and Kenton (2005) stated in their study that although academic teaching staff was having sufficient skills to integrate ICT in their teaching, they were innovative and easily overcome obstacles, they did not integrate technology consistently both as a teaching and learning tool. Gülbahar (2008) indicated that although the majority of instructors believed that technology usage was important for teaching, they lacked confidence and understanding during the integration process. The technologies of information and knowledge, especially the Internet, are encouraging many institutions to transform their processes in order to enable access to information and knowledge and thus, institutions are able to adapt themselves to new development and new 
professional profiles (Durat and Mengual-Andrés, 2014). Laabidi (2017) stated that the use of ICT in higher education institutions has faced several challenges related to the attitudes of academic teaching staff. Academic staff may want to explore using ICT in their teaching through online tests/quizzes, calendars, attendance records, portfolios, online polling/responsive systems, virtual office hours, as well as the possibility of simulations or virtual experiments, in both science, technology, engineering and mathematics and the social sciences fields (Fichten et al., 2018). According to Blau and Shamir-Inbal (2017), the more frequently teachers made use ICT in classroom, the more were their beliefs about the benefits of ICT; making the teachers felt digitally more competent. ICT has the power to widen educational opportunities but most academic staff does not use technology as an instructional delivery system as many educational institutions fail to integrate technology into the existing context.

\subsubsection{Gender and ICT}

While women continue to do well in acquiring the general forms of human capital that can be learnt in formal education, they do less well in acquiring the specific technical skills that appear most relevant to science, engineering and technology (SET) (Walby, 2011). The gendered composition of SET might be a consequence of the gendered culture of science and technology (Walby, 2011), thus resulting in the under-representation of women in SET. Galyani Moghaddamp (2009) reported that women considered themselves as being less confident and capable to use computing equipment; women assumed that they were less experienced than their male colleagues in information technology (IT) related skills and had generally negative attitudes towards the use, importance and relevance of IT to their academic studies and future careers. Women felt that there are obstacles, which prevented them from acquiring ICT skills in the educational system (Caprile and Pascual, 2011). Gender plays a crucial role in the actual computer integration in educational institutions (Sang, Valcke, Van Braak and Tondeur, 2010). Kay (2007) indicated that males tended to have more positive attitudes and higher abilities towards the use of computers. Markauskaite (as cited in Galyani Moghaddamp, 2009) reported that major differences between males and females were observed for technical ICT skills. ICT is viewed as a social creation which is not gender neutral thus resulting in a gender gap in accessing and using ICT among all nations in the world (Galyani Moghaddamp, 2009). Studies have shown that socio cultural beliefs created a gender bias, which influenced the relationship between gender and ICT.

\subsubsection{Gender and ICT Integration in Teaching}

According to Tabassum and Shehzadi (2018), academic teaching staff of public universities, were aware of the importance of ICT in the education sector but due to their age, their competence level of using computers was low and most of them never had the opportunity to attend any training. Training is a basic requirement for women's participation in the global information economy (Olatokun, 2017). A research by Rather and Kuraishy (as cited in Lentilalu, 2015) attributed the slow rate of ICT integration in the curriculum to the gender aspect where the female academic teaching staff fails to access computers due to inadequate time and lack of technical skills. In their research, Ahmadi, Keshavarzi and Foroutan (2011) stated that male teachers generally have more self-confidence than female teachers to use ICT and to communicate with students in the process of teaching and learning.

\subsection{Theoretical Framework}

This study was based on the theory of Technological Acceptance Model, developed by Davis, Bagozzi and Warshaw (1989) as shown in Figure 1.

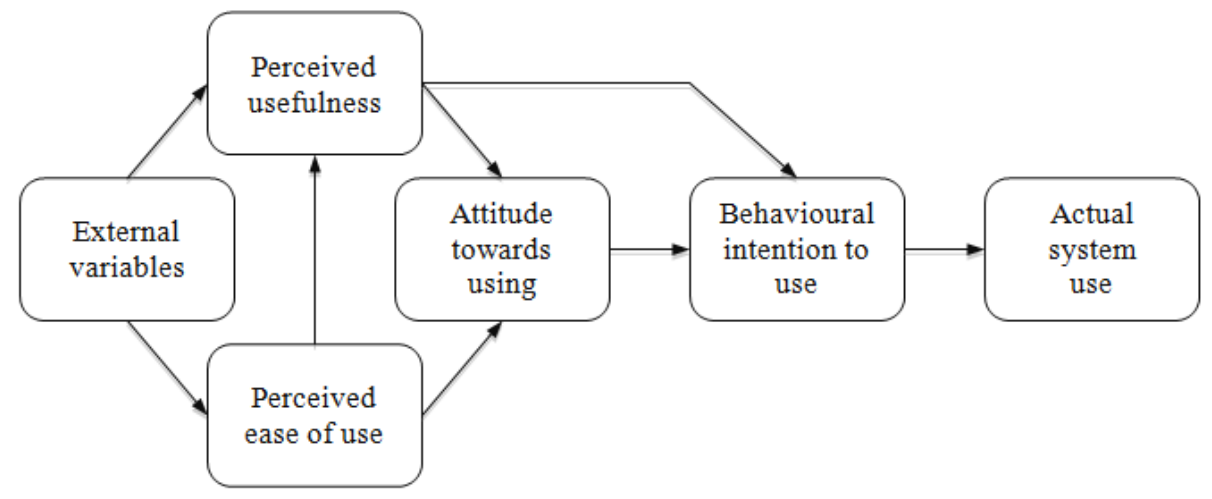

(Source: Davis, Bagozzi \& Warshaw, 1989)

Figure 1. Technology Acceptance Model 
The theory presents a basis for mapping out the effects of external variables on internal beliefs, attitudes and intentions of the user towards a new technology. Davis, Bagozzi and Warshaw (1989) formulated two more theories under the Technology Acceptance Model (TAM): Perceived Usefulness and Perceived Ease of Use. The Perceived Usefulness is seen as a potential user's personal probability to understand the benefits and value of an innovation. The Perceived Ease of Use refers to an extent to which the potential adopters expect a new technology to be easy to use and to integrate it in daily classroom practices. Davis, Bagozzi and Warshaw (1989) theory of TAM was used, as it is relevant to the study.

The relevance of Davis, Bagozzi and Warshaw (1989) theory of TAM to this study is as follows:

i. External variables: Predict concealed behaviours, motivation and intentions of the female academic teaching staff toward adoption and use of ICT in the teaching process. As ICT has been predominantly considered as a male field, the social belief makes some women still believe that ICT is not meant for women.

ii. Perceived usefulness: ICT is a powerful tool, which can enhance the teaching process of female academic teaching staff. The female academic teaching staff are not making effective use of the ICT tools, which can make their teaching process interesting.

iii. Perceived ease of use: Female academic teaching staff believes that the integration of ICT in their teaching process can be cumbersome and complicated. Such academic teaching staff prefer not to integrate ICT in their teaching process and they stick to their old-fashioned teaching methods.

iv. Attitude towards using: Gender bias in attitudes towards women using ICT is a cultural aspect which prevents female academic teaching staff from using ICT, compared to their male colleagues.

v. Behavioural intention to use: Female academic teaching staff is not interested in integrating ICT in their teaching process. They do not intend to innovate their teaching methods.

vi. Actual system use: The infrastructure provided by higher education institutions does not allow the maximal use of ICT tools in the teaching process. In this regard, most female academic teaching staff continue to use their old teaching methods that they have been using for years.

The Davis, Bagozzi and Warshaw (1989) theory of TAM enabled to unleash some factors that prevent the integration of ICT in the teaching process of female academic teaching staff in the higher education sector and by providing ways on how to combine gender, ICT and knowledge society and to be able to make recommendations so that Mauritius can aim in becoming a knowledge hub.

\section{Methodology}

Futures thinking methodology is known as a vast range of methods, theories, and findings (Miller, 2003) which, aids persons to reflect helpfully about the future (Codd et al., 2002). The futures thinking has been used as a methodology in this study to enhance the development of the future through scenarios of possible and probable futures of ICT integration in teaching by female academic teaching staff in the higher education sector in Mauritius. The thrust of futures thinking methodology in this study is to precisely and carefully improve national decisions through the exploration and creation of preferable as well as probable futures. The methodology encompasses the analysis of how those circumstances or situations may alter consequently the development and implementation of Government policies, and the causes that these policies may have on the society. Many organisations make use of futures thinking methodology to improve and understand future markets. Policy makers use the future methods to widen, develop and test possible as well as desirable future visions. Futures methodology can facilitate the development of policies (long-term), strategies, and procedure. Collection and gathering of data for this study were from both primary and secondary sources. Primary sources included journal articles and published national and international reports from Governments and other renowned organisations. Data collected from the different signals and trends in ICT was put under political, economic, social, technological, legal and environmental in a PESTLE analysis. A 'Futures wheel' for the ICT integration in teaching by female academic staff in Mauritius was drawn from the signals and trends identified. The PESTLE Analysis has allowed combining the political, economic, social, technological, legal and ethical factors that influence ICT integration in the teaching process of female academic teaching staff in the higher education sector in Mauritius. The PESTLE analysis has proved to be an effective tool for futures thinking and identifying alternative futures of the country. PESTLE analysis together with effective brainstorming helped to answer the research questions of this study. 


\section{Data Analysis and Result}

\subsection{PESTLE Analysis}

There are various enabling and restraining factors that are influencing ICT integration in the teaching process of female academic teaching staff in the higher education sector in Mauritius as elaborated in Table 1.

Table 1. Factors Influencing ICT integration in teaching by female academic teaching staff in the higher education sector in Mauritius

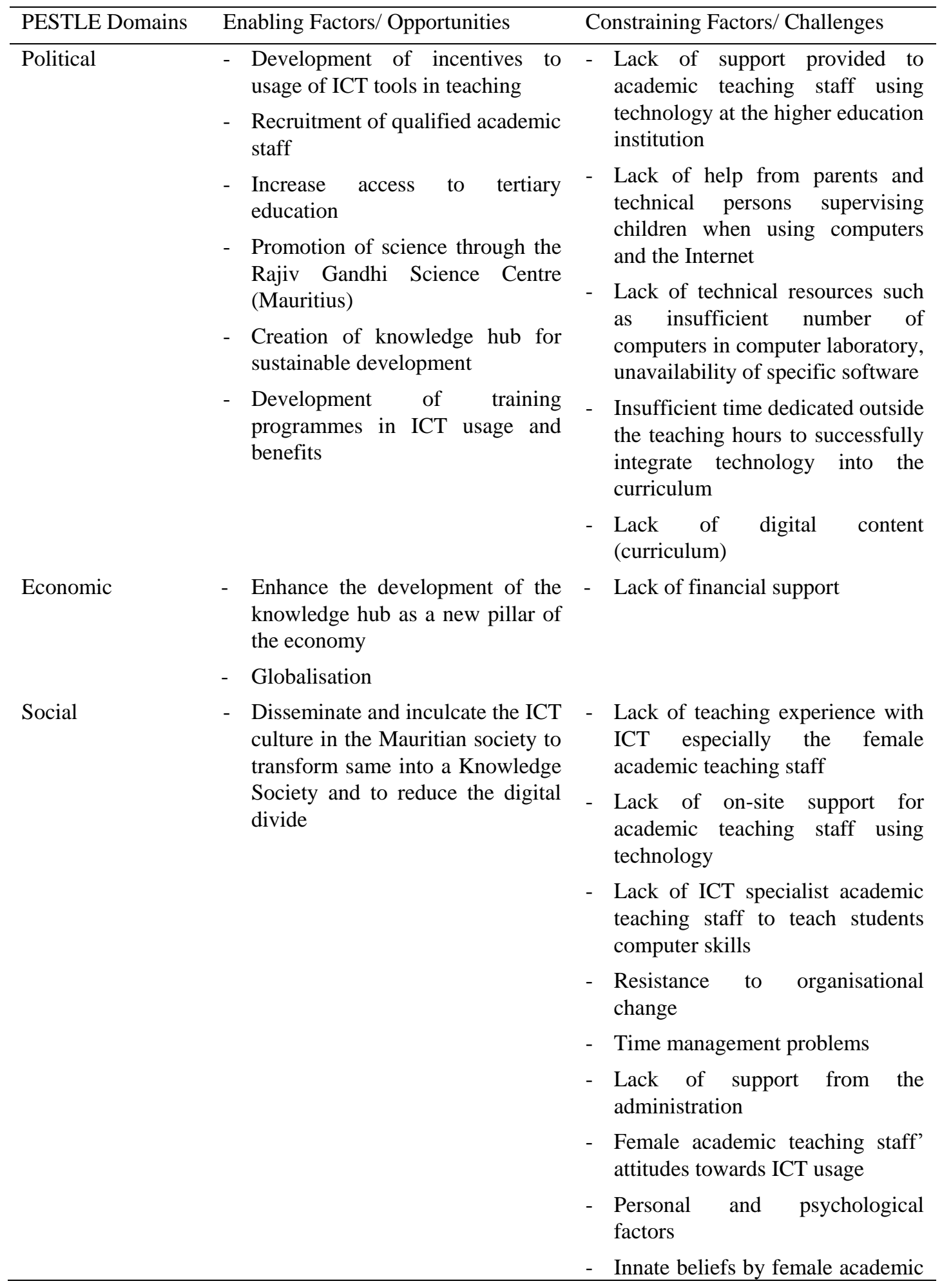




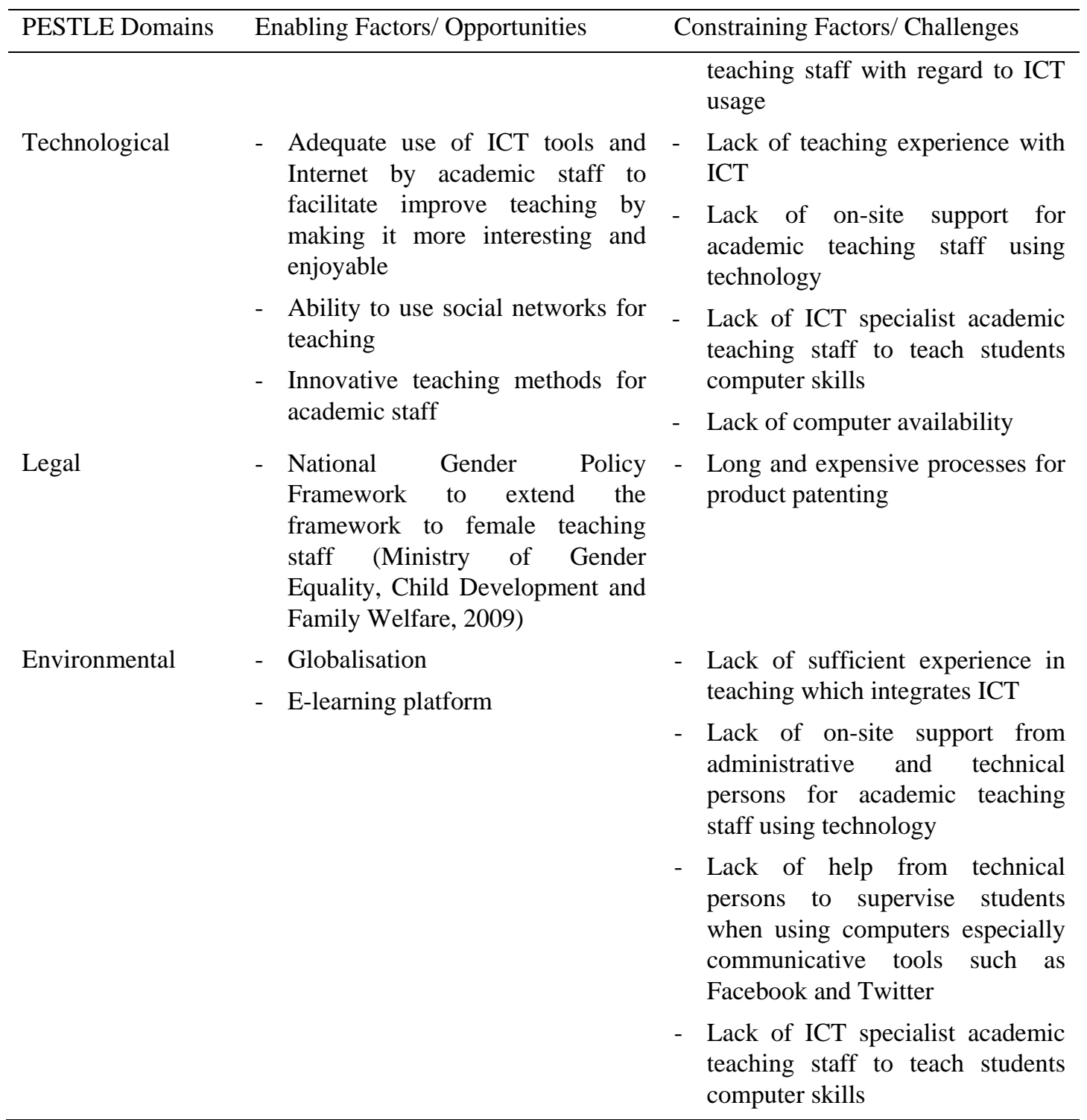

In the study, the future thinking methods (signalling, horizon scanning, future wheel analysis and alternate futures framework) produced some detailed findings, conclusion and recommendations. Signals were identified and were used to develop future changes in ICT integration in the teaching process of female academic teaching staff in the higher education sector to address the digital divide.

\subsection{Signalling and Horizon Scanning}

In line with the signalling and horizon scanning analysis, the signals and trends have been identified in Table 2 for higher education related to ICT, gender and higher education in Mauritius. 
Table 2. Signals and trends identified

Signals
$\begin{aligned} & \text { Signal 1: Enhancing quality of higher } \\ & \text { education }\end{aligned}$

Description: The Tertiary Education Strategic Plan 2013-2025 emphasises a lot on enhancing quality and importance of higher education in Mauritius as one of its main objectives, in relation of the development of a Knowledge Society. Teaching and learning in higher education is linked to the quality aspect of the programmes being offered in higher education institutions. Quality encompasses reviewing regularly the curriculum, teaching and learning methodology, integrating new developments and technology in line with the current trends in the country, especially in terms of labour market demands.

\section{Implications:}

Good integration of new developments and technology into the teaching process will lead to:

- Improved efficiency in the higher education institution at all levels if effective use of ICT is made.

- Improvement in communication channels as email, discussion groups, Facebook, Twitter and chat rooms are used

- Frequent use of ICT across different curriculum subjects ranging from Humanities to Computing, can motivate students' learning process thus resulting in better results

ICT can be an excellent driver to improve the quality of higher education. ICT integration by academic staff (especially female academic staff) can motivate students, as most students are generally fond of this digital world. This can also be an encouragement for female academic staff to come out of this so called gender gap in ICT and appreciate how ICT can enhance and facilitate the teaching process.

Exciting to learn: ICT tools such as videos, television and multimedia computer software which mix text, sound, and colourful, moving images can be very interesting for the academic staff to provide motivating and real content that will help the student to have an effective learning. Such use and integration of ICT in the curriculum will empower all academic staff in

\section{Trends}

1. Introduce Wi-Fi facilities in all campuses

Most higher education institutions offer Wi-Fi facilities on campus.

\section{Capacity Building}

- Academic teaching staff holds a Postgraduate Diploma in Higher Education;

- ICT training is a compulsory element of teacher training. 


Signals
their teaching process, thus compelling female
academic staff to enjoy using such tools. This
will provide female academic staff the
opportunity to connect with their male
colleagues and as well as to participate in real
world events. This will help in diminishing the
gender gap barrier, which exists between ICT
and female academic staff.
Facilitating the acquisition of basic ICT skills:
The communication of basic ICT skills and
concepts that will help in innovative thinking
skills can be facilitated by ICT. Female
academic staff will be encouraged to acquire
ICT skills, which can be implemented in their
teaching process, rather than using ICT for only
administrative purposes.
Enhancing academic teaching staff training: ICT
have also been used to improve access to and the
quality of academic teaching staff training.
This will be an incentive for the female
academic staff to acquire technical and practical
skills.

Signal 2: The Gender Policy Statement for the Education and Human Resources Sector

Description: Girls and boys, men and women need to enjoy equal opportunities to achieve outcomes, based on their individual talents and efforts.

Implication: It will build gender sensitivity and incorporate gender equality objectives in all the strategic goals, objectives and activities of its human resource development subsector. It will ensure a more robust Human Resource Development value chain linking education, training and employment by taking into account gender-based differences in opportunities and barriers and where both women and men are able to use state of the art technology.

\section{Trends}

\section{Improve the teaching backbone in higher education institutions}

A measure that has been taken by Government is that thirty experienced international lecturers will be recruited and posted in state universities to foster greater research and improve teaching standards (MoFED, 2014). This will help academic staff to gain exposure in terms of teaching practices.

\subsection{Future Wheel Analysis}

The future wheel analysis has been carried out to come up with the findings. The outcome of the future wheel analysis is depicted in Figure 2.

The first direct impact of the Tertiary Education Strategic Plan 2013-2025 (Improving quality of higher education) would be an increase in incentives for integration of ICT in teaching in the higher education sector. The incentives can also apply to different sectors and their consequences will also vary across the different sectors. Increase the funding in ICT equipment and tools in higher education institution would be one such incentive. This will automatically increase capacity building and improvement in ICT infrastructure in the country and especially in higher education institution. This will change Mauritius from a consumer of ICT to a creator of ICT. 
In addition, the development of ICT culture in Mauritius will encourage the academic staff to integrate ICT in their teaching process. As such, less time will be spent on chalk and talk during lectures and multimedia technologies will be the new teaching practices.

ICT will be perceived as a tool that academic teaching staff uses to help students to be more productive. The usage of ICT would enable the lectures to be more innovative, captivating and more lively for the academic staff as well as the students. This will also increase motivation amongst students by making learning enjoyable and interactive.

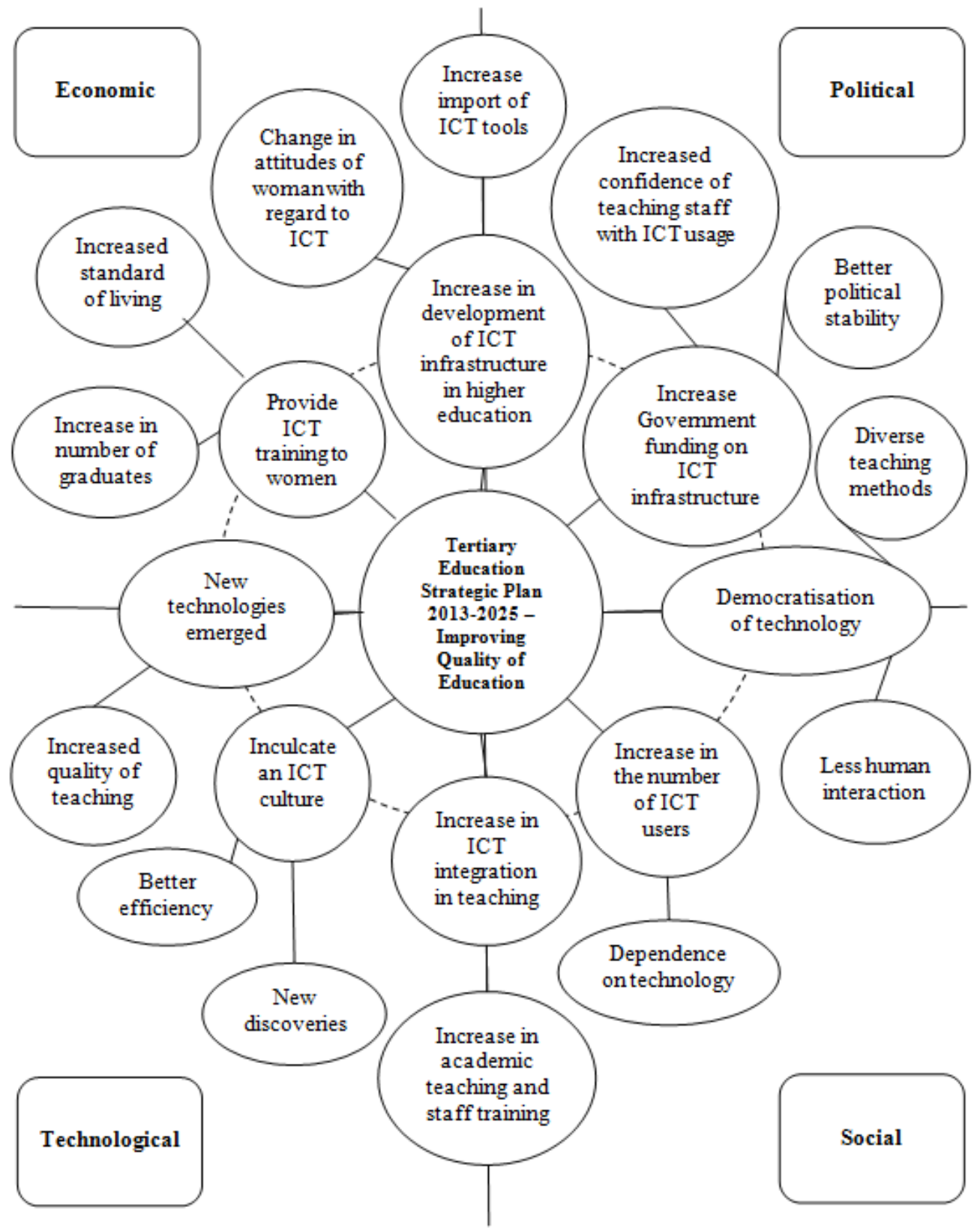

Figure 2. Futures wheel diagram

The most probable and preferable future is developed based on futures thinking methodology. The probable future for Mauritius is elaborated as an island where ICT is integrated in the classroom and the preferable future is the implementation of a National Open Source Policy and Strategy. The trends/signals found in the probable and preferable scenarios reveal that the Mauritian Government is putting a lot of emphasis in building the Mauritian economy by developing ICT as an important pillar. 


\subsection{Probable Scenario}

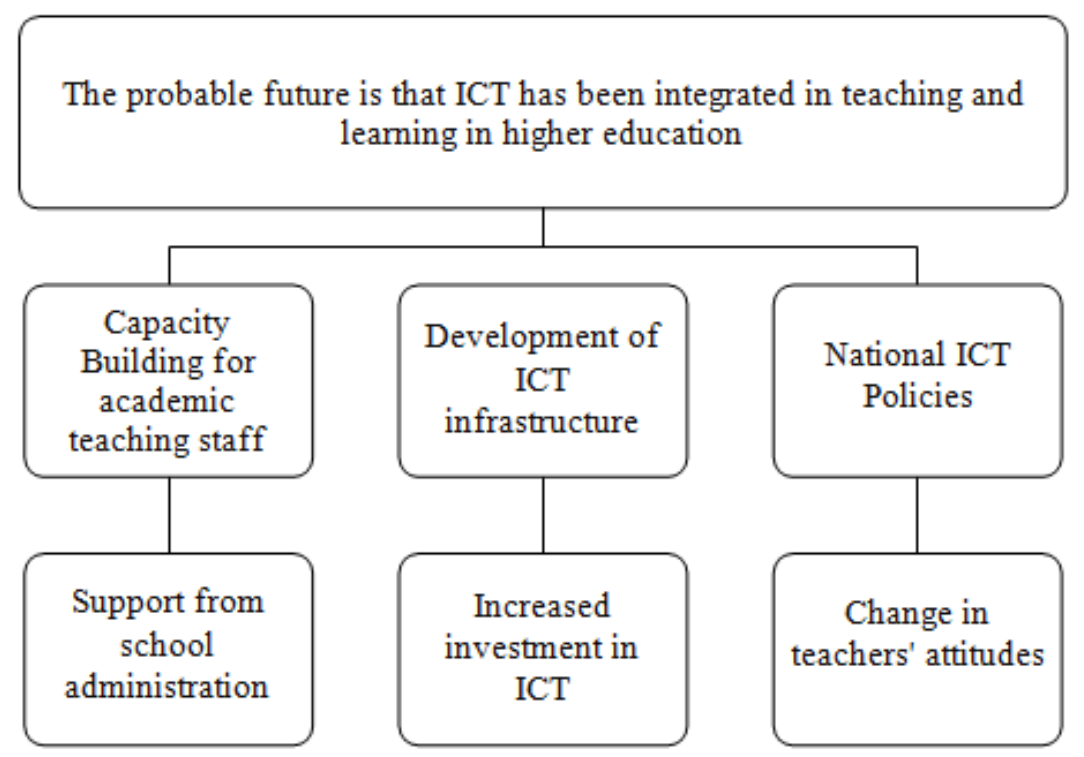

A probable scenario is illustrated in Figure 3.

Figure 3. Matrix for Probable Scenario

The probable scenario analyses the future where Mauritius has effectively implemented the integration of ICT in teaching in higher education sector. ICT has been a facilitator to the economic growth of the country although Mauritius is scarce of natural resources. This growth has been possible as a result of an empowered population who is able to understand and grasp the ICT irrespective of age and gender. Mauritius has been able to produce a myriad of ICT specialists as a result of development of ICT infrastructure and increased investment in ICT. Moreover, capacity building of academic teaching staff and continued professional development have helped in the teaching process, which have been possible from maximised investments in ICT. Although academic teaching staff remain central to the learning process, the implementation of National ICT polices has led to a shift in the role of academic teaching staff utilising ICT to that of a facilitator rather than serving as leaders in the classroom. With the support of school administrator, ICT has enabled academic teaching staff to transform their teaching practices, given a set of enabling conditions. Academic teaching staff's pedagogical practices, attitudes and reasoning have influenced their uses of ICT.

ICT is seen as a tool to help academic teaching staff create more 'learner-centric' learning environment. The effective use of ICT in teaching has challenged pupils' understanding and thinking, either through whole-class discussions or individual/small group work using ICT. ICT has enabled the move from traditional 'teacher-centric' teaching styles to more 'learner-centric' methods. The use of ICT as presentation tools (through overhead and LCD projectors, television, electronic whiteboards, guided web-tours) has been seen to be of mixed effectiveness. ICT has promoted class understanding of and discussion about difficult concepts (especially through the display of simulations), such uses of ICT have strengthened traditional pedagogical practices and diverted focus from the content of what is being discussed or displayed to the tool being utilised.

Academic teaching staff has extensive, on-going exposure to ICT, which has enabled them to evaluate and select the most appropriate technologies. However, the development of appropriate pedagogical practices to include ICT has been seen as more important than technical mastery of ICT. The use of ICT in teaching and learning activities appears to be more useful to students than specific instructions in 'computer classes'. ICT tools are now ubiquitous and fully being used by academic staff in the teaching process. 


\subsection{Preferable Scenario}

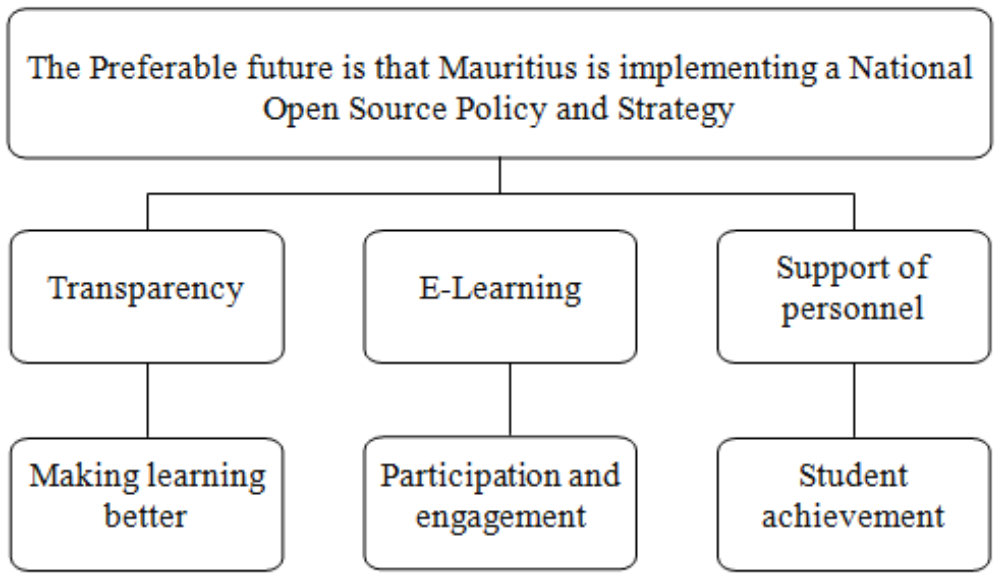

Figure 4. Matrix for Preferable Scenario

The preferable scenario in Figure 4 analyses the future where in order for Mauritius to prosper, it is promoting open data. The effect of globalisation on Mauritius has resulted in the implementation of open data, which enables the release of information by public and private organisations thus allowing the sharing of information/data.

The most crucial benefit of open data for higher education is that it allows higher education institutions to improve efficiency. Consequently, efficiency is improved by enhancing the way teaching is taking place through more effective teaching strategies. Overall students' performance can be viewed by parents and students which will in turn provide information on choices of schools, grades, discipline and so on. When using open data, privacy and ethical issues about academic teaching staff, non-academic staff and students are taken into consideration.

When using open data in education, the following has taken place:

(i) High utilisation of ICT tools by academic teaching staff particularly given that data on the impact of these tools and Open Educational resources are published regularly;

(ii) Improved instruction/digital content: making use of data on performance of student and learning techniques of the students to personalise lectures.

Furthermore, the implementation of the National Open Source Action Plan and the operationalisation of the National Open Source Policy and the National Open Source Strategy, have created the right environment for the adoption, development and use of Open Source Software in the educational sectors, public and private organisations as well as the civil society. The Open Source Software has been used as a lever for the development of the information society to enhance the competitiveness of the economy and to lower financial and technical barriers to access new ICT technologies, through e-learning, transparency and student achievement.

\section{Discussion}

\subsection{Major Findings}

Based on the signals and trends identified in this study, it can be observed that the Government of Mauritius is leaving no stone unturned to develop the ICT sector. The two signals identified were namely Enhancing Quality of Higher Education (which forms part of the Tertiary Education Strategic Plan 2013-2025) and Gender Policy Statement for the Education and Human Resources Sector. The Government through its public institutions directly or indirectly related to ICT is shaping the priority fields for intervention in the education sector, so as to create a conducive environment (physical infrastructure, capacity building) that will accommodate ICT in classrooms.

The main objective of the research was to make ICT a part of the teaching tool. In that effort, the ICT sector was explored based on the documentation available such as Government policies and national as well as international reports from public and private organisations, using futuristic tools. The gaps were identified and situation of the higher education sector has been explored by employing the alternative futures thinking methods such as signalling, horizon scanning and future wheels analysis.

Using futures wheel techniques, the trends and signals of both the probable and preferable scenarios have been developed. The scenarios proved quite reasonable based on the trends and signals of the scenarios and policy 
recommendations have been proposed to integrate ICT in the higher education sector particularly for female teaching staff in Mauritius. The answers to the research questions for the study were answered.

\subsection{Recommendations}

The following recommendations will assist to construct an effective ICT integration by female academic teaching staff in higher education institution in Mauritius:

\section{a) Enhance capacity building for academic teaching staff}

More emphasis should be put on the ICT skills of academic teaching staff. Higher education institution should design a specific training programme for academic teaching staff. Such training programme should cover presentation skills, communicative tools and use of software that would enhance the teaching process and make the teaching process exciting. Upon completion of such a training programme, an academic teaching staff would be issued a Certificate. As the Government has decided that all academic teaching staff should possess a Postgraduate Diploma in Higher Education, the above mentioned Certificate should also be a requirement to the post of academic teaching staff. To encourage women to consider ICT as an interesting and enjoyable tool and to make women realise that ICT does not belong to men only, special training programmes especially for women academic teaching staff should be organised. Such training programmes will be beneficial to women, especially those who lack ICT skills, to enable them to be more confident when using ICT during the teaching process.

b) Achieve high quality higher education

With effective use of ICT in the teaching process, the quality of higher education offered in the local institutions will increase. All academic teaching staff will integrate ICT in their teaching process. This will give rise to more effective learning by the students as the delivery of lectures will be enjoyable and up-to-date with the digital content, and such strategies concur with the concept of globalisation. Moreover, when the students will do well in their studies, this will encourage female academic teaching staff to continue their teaching process using ICT tools.

c) Promote the ICT culture amongst female academic staff

In order to promote the ICT culture amongst the target group of this study that is female academic teaching staff, Government should promote awareness programmes for the use of ICT and its benefits and extend such programmes to women across the country irrespective of age. Awareness programmes could be conducted at the first instance in community centres across the island and female academic teaching staff could deliver such programmes. This will enable the female academic teaching staff to meet other women who may be less at ease with the use of ICT and they will be able to share their experience and thus increase their confidence.

d) Strengthen financial support to higher education institutions (both public and private)

Government should increase the fund granted to public higher education institutions. This will enable them to improve ICT infrastructure (well-equipped lecture theatres or classrooms with all the latest technologies and software; well designed digital curriculum content without any gender bias, Internet as a necessity, computers to all teaching academic staff, special technical support provided to female academic staff who feel less confident when using ICT in the teaching process). On the other hand, private higher education institutions could be granted funding, based on the size of their student population, so as to encourage them to invest in ICT infrastructure. In order for Mauritius to become a knowledge society and a knowledge hub in the Indian Ocean, it is imperative that the private higher education institutions make full use of ICT.

\section{Conclusion}

A number of institutions/organisations, both public and private, is making a lot of effort towards the development of ICT in Mauritius. As proposed in the Tertiary Education Strategic Plan 2013-2025, the Ministry of Education and Human Resources, Tertiary Education and Scientific Research is providing various incentives to academic teaching staff and encouraging them to integrate ICT in their teaching process. Another critical component is the capacity building at national level; there should be more ICT specialists, technologists and innovators who would help in the design of innovative teaching techniques and tools. Adequate investment should be done on the ICT infrastructure in higher education institutions to help to improve teaching. Mauritius should have collaborative linkages with organisations/institutions in developed countries whereby funding could be sought from. The collaborative linkages with developed countries will enable Mauritius to learn from those countries in terms of ICT implementation in education. Mauritius aspires to make ICT one of the pillars of the knowledge society. To make this a reality, measures such as, implementing evidence-based national ICT policies, building human competency in ICT related 
fields, enhancing ICT infrastructure, promoting the role of ICT in society and increasing investment in ICT are required.

\subsection{Way Forward}

ICT can unlock doors of opportunity long closed by the geographical location of Mauritius, by enabling education beyond the classroom through e-learning. This can increase access to higher education and attract international students who wish to study at a higher education institution in Mauritius. Furthermore, ICT can provide new approaches for academic teaching staff to contribute in positioning Mauritius on equal standing with advanced economies.

\section{References}

Achimugu, P., Oluwagbemi, O., \& Oluwaranti, A. (2010). An evaluation of the impact of ICT diffusion in Nigeria's higher educational institutions. Journal of Information Technology Impact, 10(1), 25-34. Retrieved from: https://www.researchgate.net/profile/Philip_Achimugu/publication/267250476_An_Evaluation_of_the_Impact_ of_ICT_Diffusion_in_Nigeria's_Higher_Educational_Institutions/links/5465695d0cf2f5eb17ff3a89/An-Evaluati on-of-the-Impact-of-ICT-Diffusion-in-Nigerias-Higher-Educational-Institutions.pdf

Ahmadi, S., Keshavarzi, A., \& Foroutan, M. (2011). The application of information and communication technologies (ICT) and its relationship with improvement in teaching and learning. Procedia-Social and Behavioral Sciences, 28, 475-480. https://doi.org/10.1016/j.sbspro.2011.11.091

Almekhlafi, A., Ismail, S., \& Al-Mekhlafy, M. H. (2017). Male and female language teachers' technology integration differences in elementary schools in the United Arab Emirates. International Journal of Research Studies in Educational Technology, 6(1), 1-14. https://doi.org/10.5861/ijrset.2016.1521

Almerich, G., Orellana, N., Suárez-Rodríguez, J., \& Díaz-García, I. (2016). Teachers' information and communication technology competences: A structural approach. Computers \& Education, 100, 110-125. https://doi.org/10.1016/j.compedu.2016.05.002

Alsharidah, M. (2018). Creating change in the use of information and communications technology by female Islamic studies teachers in Saudi Arabia. International Journal of Educational Administration and Policy Studies, 10(3), 17-24. https://doi.org/10.5897/IJEAPS2018.0545

Bauer, J. \& Kenton, J. (2005). Toward Technology Integration in the Schools: Why It Isn't Happening. Journal of Technology and Teacher Education, 13(4), 519-546. Norfolk, VA: Society for Information Technology \& Teacher Education. Retrieved from https://www.learntechlib.org/primary/p/4728/.

Blau, I., \& Shamir-Inbal, T. (2017). Digital competences and long-term ICT integration in school culture: The perspective of elementary school leaders. Education and Information Technologies, 22(3), 769-787. https://doi.org/10.1007/s10639-015-9456-7

Caprile, M., \& Pascual, A. S. (2011). The Move Towards the Knowledge-based Society: a Gender Approach. Gender, Work \& Organization, 18(1), 48-72. https://doi.org/10.1111/j.1468-0432.2010.00534.x

Ciolan, L., Petrescu, A., Radulescu, C., \& Bucur, C. (2014). Training teachers to use digital resources for the knowledge society. Procedia-Social and Behavioral Sciences, 128, 415-419. https://doi.org/10.1016/j.sbspro.2014.03.180

Codd, J., Brown, M., Clark, J., McPherson, J., O'Neill, H., O’Neill, J., Waitere-Ang, H. \& Zepke, N. (2002). Review of future-focused research on teaching and learning. Wellington: Ministry of Education.

Davis, F. D. (1993). User acceptance of information technology: system characteristics, user perceptions and behavioral impacts. International journal of man-machine studies, 38(3), 475-487. https://doi.org/10.1006/imms.1993.1022

Davis, F. D., Bagozzi, R. P., \& Warshaw, P. R. (1989). User acceptance of computer technology: a comparison of two theoretical models. Management science, 35(8), 982-1003. https://doi.org/10.1287/mnsc.35.8.982

Demir, O., Genc, E. G., Alp, E. A., \& Yildirim, F. (2015). A New Knowledge Society Index: Global Tendencies and an Analysis of Turkey. Educational Sciences: Theory and Practice, 15(2), 325-335. https://doi.org/10.12738/estp.2015.2.2356 
Duart, J. M., \& Mengual-Andrés, S. (2014). IMPACT OF THE KNOWLEDGE SOCIETY IN THE UNIVERSITY AND IN SCIENTIFIC COMMUNICATION. RELIEVE-Revista Electrónica de Investigación y Evaluación Educativa, 20(2). https://doi.org/10.7203/relieve.20.2.4343

Fichten, C., Jorgensen, M., Havel, A., King, L., Lussier, A., Asuncion, J., ... \& Amsel, R. (2018). Information and Communication Technologies: Views of Canadian College Students and "Excellent" Professors. Journal of Education and Training Studies, 6(9), 1-12. https://doi.org/10.11114/jets.v6i9.3390

Galyani Moghaddam, G. (2010). Information technology and gender gap: toward a global view. The electronic library, 28(5), 722-733. https://doi.org/10.1108/02640471011081997

Government of Mauritius, The Gender Policy Statement for the Education and Human Resources Sector. (2009). Retrieved from: http://ministry-education.govmu.org/English//DOCUMENTS/GENDER\%20POLICY\%20STATEMENT\%20F OR\%20THE\%20EDUCATION\%20AND\%20HUMAN\%20RESOURCES\%20SECTOR.PDF

Government of Mauritius. (2008). The National Gender Policy Framework. Retrieved from: http://www.unesco.org/education/edurights/media/docs/7526a4d03a2047d7db44ad3f63c982f80d75501e.pdf

Gulbahar, Y. (2008). ICT Usage in Higher Education: A Case Study on Preservice Teacher and Instructions. Online Submission, 7(1).

Hanemann, U. (2014). Harnessing the Potential of ICTs for Literacy Teaching and Learning: Effective Literacy and Numeracy Programmes Using Radio, TV, Mobile Phones, Tablets, and Computers. UNESCO Institute for Lifelong Learning. Retrieved from: https://files.eric.ed.gov/fulltext/ED560504.pdf

Kay, R., 2007. Gender differences in computer attitudes, ability, and use in the elementary classroom. Ontario, Ministry of Education (Monograph \#8, 1-4).

Kler, S. (2015). ICT integration in teaching and learning: Empowerment of education with technology. https://doi.org/10.15415/iie.2014.22019

Krause, M., Pietzner, V., Dori, Y. J., \& Eilks, I. (2017). Differences and Developments in Attitudes and Self-Efficacy of Prospective Chemistry Teachers Concerning the Use of ICT in Education. Eurasia Journal of $\begin{array}{llll}\text { Mathematics, Science } & \text { Technology }\end{array}$ https://doi.org/10.12973/eurasia.2017.00935a

Laabidi, H. (2017). English Professors' Attitudes towards the Use of ICT in Moroccan Universities. IJEFL, I(2). Retrieved from: http://ijefl.com/index.php/ijefl/article/view/9/8

Miller, R. (2003). Where schools might fit in a future learning society. Incorporated Association of Registered Teachers of Victoria.

Ministry of Education and Human Resources, Tertiary Education and Scientific Research. (2015). Education Reform: National Curriculum Framework 2015 launched. Retrieved from: http://www.govmu.org/English/News/Pages/Education-Reform-National-Curriculum-Framework-2015-launche d.aspx

Ministry of Finance and Economic Development (MoFED). (2014). Budget Speech 2014 - Building a better Mauritius, Creating the next wave of prosperity. Retrieved from: http://mof.govmu.org/English/Documents/Budget2014/BudgetSpeech2014.pdf

Ministry of Tertiary Education, Science, Research and Technology (MoTESRT). (2013). Tertiary Education Strategic Plan 2013-2025.

Muro, C., \& Gabriel, M. (2016). Women Engagement in ICT Professions in Tanzania: Exploring Challenges and Opportunities. Women, 5(05). Retrieved from: https://www.ijcit.com/archives/volume5/issue5/Paper050505.pdf

OECD. (2009). Centre for Educational Research and Innovation. The starter pack: Futures Thinking in Action, 2009. Retrieved from: http://www.oecd.org/edu/school/schoolingfortomorrowthestarterpackfuturesthinkinginaction.htm

OECD. (2014). Talis 2013 Results: An International Perspective on Teaching and Learning, OECD Publishing. https://doi.org/10.1787/9789264196261-en 
Olatokun, W. M. (2017). Availability, accessibility and use of ICTs by Nigerian women academics. Malaysian Journal of Library \& Information Science, 12(2), 13-33. Retrieved from: http://jice.um.edu.my/index.php/MJLIS/article/view/6994/4652

Onwuagboke, B. B. C., \& Singh, T. K. R. (2016). Faculty attitude and use of ICT in instructional delivery in tertiary institutions in a developing nation. International Journal of Research Studies in Educational Technology, 5(1), 77-88. Retrieved from: https://doi.org/ 10.5861/ijrset.2016.1428

Prabowo, H. (2007). The concept and strategy of ICT integration in teaching and learning process at Bina Nusantara University-Jakarta. In Innovations in E-learning, Instruction Technology, Assessment, and Engineering Education (pp. 127-131). Springer, Dordrecht. https://doi.org/10.1007/978-1-4020-6262-9_23

Sahlberg, P. (2010). The secret to Finland's success: Educating teachers. Stanford Center for Opportunity Policy in Education, 2, $\quad 1-8 . \quad$ Retrieved from: http://www.nnstoy.org/download/preparation/Secret\%20to\%20Finland's\%20Success\%20-\%20Education\%20Te achers.pdf

Sang, G., Valcke, M., Van Braak, J., \& Tondeur, J. (2010). Student teachers' thinking processes and ICT integration: Predictors of prospective teaching behaviors with educational technology [online], 54(1). https://doi.org/10.1016/j.compedu.2009.07.010

Semenov, A. (2005). Information and Communication Technologies in Schools: A Handbook for Teachers or How ICT Can Create New Open. France: Division of Higher Education. Retrieved from UNESCO website: http://unesdoc.unesco.org/images/0013/001390/139028e.pdf

Tabassum, S., \& Shehzadi, K. (2018). ICT Awareness among Faculty Members of The Public Sector Women Universities of Pakistan (No. 009). https://doi.org/10.5281/zenodo.1196517

UNITED NATIONS CONFERENCE ON TRADE AND DEVELOPMENT - UNCTAD. (2014). Measuring ICT and Gender: An Assessment-Partnership on Measuring ICT for Development 2004-2014. New York and Geneva. Retrieved from: https://unctad.org/en/PublicationsLibrary/webdtlstict2014d1_en.pdf

Walby, S. (2011). Is the knowledge society gendered?. Gender, Work \& Organization, 18(1), 1-29. https://doi.org/10.1111/j.1468-0432.2010.00532.x 